\title{
E-Government Service Quality Using E-GovQual Dimensions Case Study Ministry of Law and Human Rights DIY
}

\author{
Taufiq Effendy Wijatmoko \\ Informatics Department, Faculty of Science and Technology, UIN Sunan Kalijaga, \\ J1. Marsda Adisucipto No 1 Yogyakarta 55281, Indonesia. Tel. +62-274-540971, Fax. +62-274-519739. \\ Email*: taufiq.ew@gmail.com
}

\begin{abstract}
Regional Office of the Ministry of Law and Human Rights DIY organizes a variety of public services using information technology, including correctional services, immigration services, general legal administration services, intellectual property services, communication services, data and information services, and others administrative services. All of these services cannot be separated from the role of information technology to provide services that are fast, cheap, effective and reliable to the public. This study was conducted to assess the quality Ministry of Law and Human Rights DIY e-Government service using e-GovQual dimensional framework as a best practice. This study include quantitative research involving a number of respondents for the survey. This research question based on the dimensions of e-Govqual and represent the attributes of each dimension of e-GovQual to assess the quality of Ministry of Law and Human Rights DIY e-Government service. The question must pass the validation test using Cronbach's $\alpha$. The processing of data using confirmatory factor analysis to obtain the main factors that affect each of the dimensions of e-GovQual. The Importance Performance Analysis (IPA) method helps e-Govqual to measure the level of importance and level of performance of each e-Govqual attribute by classifying it in the Cartesian quadrants, which can help ensure the quality of e-Government services according to the needs and expectations of citizens as service user. Values in IPA (concentrating here, continuing to work well, low priority, and possibly overdoing it) will be the value of quality e-Government services. The results of this study are expected to give priority as a recommendation for Information and Communication Technology to the development of e-Government services in order to improve service quality.
\end{abstract}

Keywords: e-Government, e-GovQual, IPA, services

\section{INTRODUCTION}

The level of service quality can be measured by various methods of measuring service quality. Quality of service places more emphasis on the word service user, service, quality, and level. Required methods that can be used to measure the level of service quality. One method for measuring service quality is e-Government Quality (eGovqual). Before approving e-Govqual, in previous years, the most common quality of service was approved using the Servqual method or service quality. Servqual developed by Parasuraman in 1988 Support has the ability to achieve the best grades. Servqual refers to five dimensions of measurement; reliability, responsiveness, assurance, tangibles, and empathy. Consumer Ratings are conceptualized as what consumers expect from services and the value consumers give for services that are actually received.

The Webqual method was developed by Stuart Barnes in 2000. Webqual is one of the quality measurement methods shown to measure website quality. Webqual measurement technique is done based on the perception of the end user. Webqual is a further development of the Servqual method. Websqual is used to measure internal websites such as; integrated service center, human resource services, etc.

Slightly different from Webqual or Servqual, eGovqual is more devoted to measuring the quality of government-based electronic services or e-Government. e-Govqual is a service quality measurement concept in terms of electronic services that focus on government sites or portals. Papadomichelaki and Mentzas (2001) in their discovery, divides the e-Govqual measurement scale into four dimensions, namely; efficiency, trust, reliability, and citizen support. These dimensions in the e-Govqual method will be used by researchers to measure service quality by using the attributes that exist in the four dimensions of e-Govqual as measurement variables in research. When the value of each e-Govqual attribute has been found, a method is needed to measure the importance and performance level of each attribute. Importance Performance Analysis (IPA) is a data analysis method that is expected to find out how the quality of e-Government services at the Ministry of Law and Human Rights DIY. The Importance Performance Analysis approach is depicted in a Cartesian diagram consisting of the $\mathrm{X}$ axis representing the level of performance and the $\mathrm{Y}$ axis representing the level of importance. With the help of Importance Performance Analysis (IPA), it can be found how the value of these attributes, whether classified as concentrate here, keep up the good work, low priority, or possible overkill.

The Ministry of Law and Human Rights DIY provides public services in the DIY region including: correctional services, immigration services, general legal administration services, intellectual property services, 
and other office administration services. All of these services cannot be separated from the role of information technology to provide services that are fast, cheap, effective and reliable to the public.

This study evaluated or analyzed the quality of public services in the Ministry of Law and Human Rights DIY using the E-GovQual approach. The E-GovQual instrument was developed to measure the quality of services provided by the government through websites from a public perspective. In other words, this research would like to figure out the extent of public satisfaction on service quality provided by the Ministry of Law and Human Rights DIY by descriptive analysis.

\section{MATERIALS AND METHODS}

\section{Research methodology}

The methodology used in this study has several stages of research that are in Figure 1 below. This research will first conduct a literature study on matters related to this research such as, e-Government, Quality of eGovernment, and Importance Performance Analysis. After that the data collection process will be carried out using the attributes of the e-Govqual method as in Figure 1.

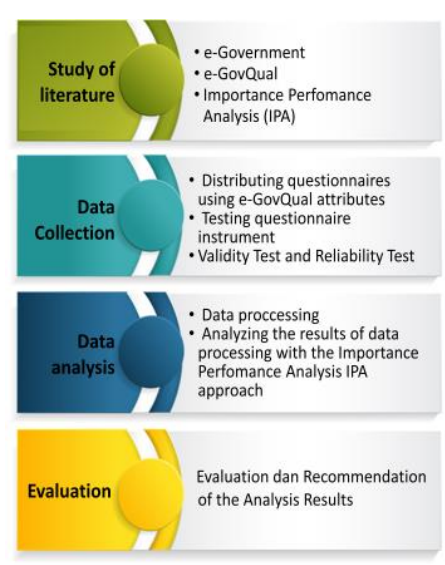

Figure 1. Research methodology workflow.

The method used in this study is a survey aimed at public municipal government Regional Office of the Ministry of Law and Human Rights DIY to know public perceptions of the quality of e-Government services provided. The tool used is a questionnaire designed based on an e-GovQual approach to measure perceived quality of e-Government services based on six dimensions such as efficiency, trust, reliability, citizen support, content \& appearance of information and functionality of the interaction environment. Thus, it can be obtained whether the service provided by the government has met citizen need or expectation. The questionnaire was design on the e-GovQual framework consisting of 4 (four) dimensions and 20 (twenty) indicators.
EGovQual is a framework developed to measure public perceptions of the quality of services from websites or e-Government portals. E-Government portal is a medium where people could obtain information or services needed. The e-Govqual model surveys large number of literature related to website quality and eservice quality. The study found several service quality attributes may be applicable for e-Government while on the other hand there are attributes that are only appropriate for some attributes suitable for eGovernment.

\section{Method of Collecting Data}

In this study, the data collection method was carried out by conducting a survey in the form of a questionnaire using the attributes of the e-Govqual dimension as a research variable. EGovQual is a model developed to measure people's perception of service quality from eGovernment websites or portals. An e-Government website or portal is a place where people can get information or services (Papadomichelaki and Mentzas, 2001). E-Government Quality (e-Govqual) which will be used in this study has 4 dimensional scales that are used as factors for measuring the quality of e-Government services. Figure 2 below shows the 4 dimensions of the e-Govqual model, namely:

\section{Efficiency}

The value of the variable is seen from the level of service convenience. In this dimension there are 6 (six) attribute.

2. Trust

The value of the variable is seen from the level of consumer confidence in using services. In this dimension there are 4 (four) attribute.

\section{Reliability}

The value of a variable is seen in terms of the usability or service capabilities (accessibility, availability, and accuracy) provided. In this dimension there are 5 (five) attributes.

4. Citizen Support

The value of the variable is seen from how the ability of services can help consumers to solve their problems. In this dimension there are 5 (five) attributes.

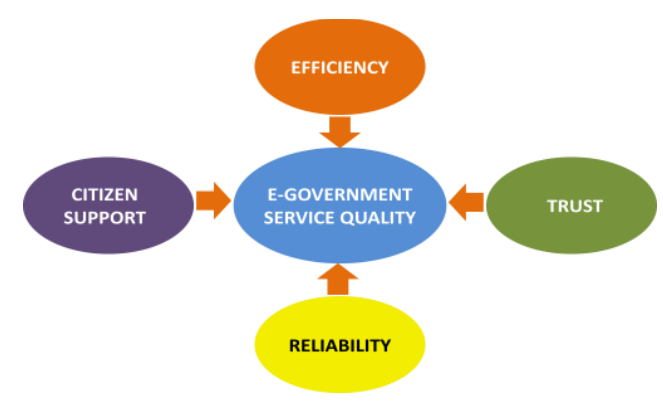

Figure 2. Dimensions of e-Govqual. 
The e-Govqual scale into 20 (twenty) pieces of attributes in 4 main scale dimensions of the measurement of the quality of e-Government services as in Table 1 below. These attributes are used as variables in this research questionnaire.

Table 1. Atributs in the e-GovQual Dimension.

\begin{tabular}{lll}
\hline No. & \multicolumn{1}{c}{ Variable } & \multicolumn{1}{c}{ Item } \\
\hline $1 . \quad$ Efficiency & e-Government site address is easy to remember (EF1) \\
& The information displayed in this e-Government site is update and fresh (EF2) \\
& This e-government site's sitemap is well organized (EF3) \\
& This e-Government site's structure is clear and easy to follow (EF4) \\
& This e-government site's search engine is effective (EF5) \\
& The information displayed in this e-Government site is apppropriate detailed (EF6) \\
& Data provided by users in this egovernment site are archived securely (TR1) \\
& Acquisition of username and password in this e-government site is secure (TR2) \\
& Data provided in this e-government site are used only for the reason submitted(TR3) \\
& Maintain the confidentiality of the use of personal data (TR4) \\
& This e-Government site is available and accessible whenever you need it (RE1) \\
& This e-Government site provides services in time (RE2) \\
& e-Government site's pages are downloaded quickly enough (RE3) \\
& This e-Government site works properly with your default browser (RE4) \\
& The ability to perform promised services accurately (RE5) \\
& Employees showed a sincere interest in solving users' problem (CS1) \\
& Employees have the knowledge to answer users' questions (CS2) \\
& Employees give prompt replies to users inquiries (CS3) \\
& Employees can convey trust and confidence (CS4) \\
4. & There is contact information (CS5) \\
&
\end{tabular}

Based on Table 1 above, thus there are a total of 20 variables or attributes of quality assessment of eGovernment services that will be used in this study. The attributes are the key that will be used to assess the extent to which e-Government service quality is felt by users of public services. In other words, this research will find out how far the level of satisfaction of service users with e-Government services, and how is the compatibility between the performance of e-Government services with the level of interest of citizens in using eGovernment services.

\section{IPA Approach}

The Importance Performance Analysis (IPA) approach is used during the data analysis process in this study. Importance Performance Analysis (IPA) is an easy method applied to identify which attributes should be improved to add the average value of community satisfaction as expected (J.A. Martilla, and J.C. James, 1977). The basis of science is the level of performance and level of importance. These two bases will show the level of community satisfaction with public services carried out at the Ministry of Law and Human Rights DIY.
To answer the problems in this study, an analysis process is needed that can assess the level of conformity between the expectations of service users and the performance of public services, namely Importance Performance Analysis (IPA). Questionnaire data that has been collected using the e-Govqual approach will be analyzed by the IPA method to determine the quality level of e-Government services based on the perspective of service users.

The analysis carried out in the IPA is the suitability level analysis, gap level analysis and quadrant analysis by mapping the priority scale to each quadrant according to the perspective of interest and performance produced (D. Napitupulu, 2016) After that, it can determine recommendations for priority attributes. The results of the IPA analysis by calculating the average value (mean) of each attribute in each dimension of e-Govqual. GAP analysis between service performance and interests shows in general the actual service performance.

The IPA approach is depicted in a Cartesian diagram consisting of the $\mathrm{X}$ axis representing the level of performance and the $\mathrm{Y}$ axis representing the level of importance. 


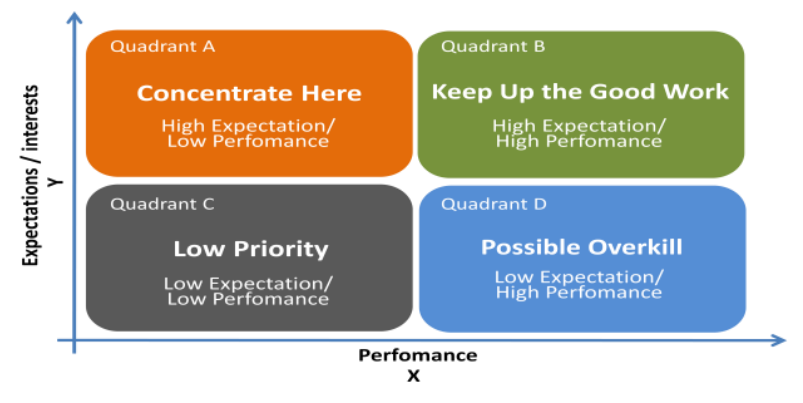

Figure 3. Quadrant in Importance Performance Analysis (IPA).

In Figure 3 there are four quadrants, namely:

1. Concentrate here (quadrant $A$ )

This quadrant shows aspects or attributes that are considered to affect customer satisfaction including service elements that are considered very important, but have not been implemented according to customer expectations. As a result the service is disappointing or the customer is not satisfied. Services in this quadrant are the organization's top priority for improvement.
2. Keep up the good work (quadrant B)

This quadrant indicates that the service has been successfully provided by the organization and is considered to have satisfied the customer or met customer expectations. Service in this quadrant is considered important by the customer so that quality must be maintained.

3. Low priority (quadrant $C$ )

The government is considered low in providing services, but service users do not consider the features of the service to be very important. So the expectation value is low and the performance value is also low. This means that there are attributes that are lacking but do not need more attention.

4. Possible overkill (quadrant D)

This quadrant shows aspects that affect customers are less important but in excessive implementation. The resources used need to be transferred to services that are considered more important such as quadrant $\mathrm{A}$ and quadrant B.

\section{RESULTS AND DISCUSSION}

\section{Results}

Table 2. Validity Testing.

\begin{tabular}{|c|c|c|c|}
\hline No. & Variable & $\begin{array}{c}\text { Corrected Item- } \\
\text { Total Correlation }\end{array}$ & Validity \\
\hline \multicolumn{4}{|c|}{ Efficiency Dimension } \\
\hline 1. & e-Government site address is easy to remember (EF1) & 0.574 & VALID \\
\hline 2. & The information displayed in this e-Government site is update and fresh (EF2) & 0.538 & VALID \\
\hline 3. & This e-government site's sitemap is well organized (EF3) & 0.680 & VALID \\
\hline 4. & This e-Government site's structure is clear and easy to follow (EF4) & 0.513 & VALID \\
\hline 5. & This e-government site's search engine is effective (EF5) & 0.621 & VALID \\
\hline 6. & The information displayed in this e-Government site is apppropriate detailed (EF6) & 0.814 & VALID \\
\hline \multicolumn{4}{|c|}{ Trust Dimension } \\
\hline 1. & Data provided by users in this egovernment site are archived securely (TR1) & 0.718 & VALID \\
\hline 2. & Acquisition of username and password in this e-government site is secure (TR2) & 0.745 & VALID \\
\hline 3. & Data provided in this e-government site are used only for the reason submitted(TR3) & 0.691 & VALID \\
\hline 4. & Maintain the confidentiality of the use of personal data (TR4) & 0.800 & VALID \\
\hline \multicolumn{4}{|c|}{ Reliability Dimension } \\
\hline 1. & This e-Government site is available and accessible whenever you need it (RE1) & 0.692 & VALID \\
\hline 2. & This e-Government site provides services in time (RE2) & 0.609 & VALID \\
\hline 3. & e-Government site's pages are downloaded quickly enough (RE3) & 0.731 & VALID \\
\hline 4. & This e-Government site works properly with your default browser (RE4) & 0.647 & VALID \\
\hline 5. & The ability to perform promised services accurately (RE5) & 0.778 & VALID \\
\hline \multicolumn{4}{|c|}{ Citizen Support Dimension } \\
\hline 1. & Employees showed a sincere interest in solving users' problem (CS1) & 0.757 & VALID \\
\hline 2. & Employees have the knowledge to answer users' questions (CS2) & 0.815 & VALID \\
\hline 3. & Employees give prompt replies to users inquiries (CS3) & 0.816 & VALID \\
\hline 4. & Employees can convey trust and confidence (CS4) & 0.707 & VALID \\
\hline 5. & There is contact information (CS5) & 0.703 & VALID \\
\hline
\end{tabular}


Based on the survey conducted, the questionnaire was distributed to 90 respondents who used the Ministry of Justice and Human Rights DIY services. Selected respondents meet the criteria of people who have used e-Government websites to search for information or services. The data that can be processed are only 82 questionnaires where incomplete data will not be included in the analysis process. Before the results of the questionnaire data are processed and analyzed, the validity and reliability of the questionnaire will be tested first. The instrument is said to be valid and reliable if the instrument can measure data accurately and the measurement results are consistent if it is repeated. The results of the validity and reliability tests can be presented in Table 2 .

The results of the instrument validity and reliability test for 82 respondents where $r$ count (corrected itemtotal correlation) must be greater than $r$ table $(r$ count $>r$ table) and $\mathrm{r}$ table for 82 respondents is 0.215 . From table 2 , it can be seen that in the Corrected Item-Total Correlation column, each variable value is more than 0.215 . Thus it can be said that all questionnaire variables are said to be valid because they meet the minimum requirements $(>0.215)$. In addition, the results of reliability testing using Cronbach Alpha (> 0.6) per dimension and all dimensions are as follows:

Table 3. Reliability Testing.

\begin{tabular}{lcc}
\hline \multicolumn{1}{c}{ Dimension } & $\begin{array}{c}\text { Cronbach's } \\
\text { Alpha }\end{array}$ & $\begin{array}{c}\text { Amount of } \\
\text { Variables }\end{array}$ \\
\hline Efficiency & 0.838 & 6 \\
Trust & 0.896 & 4 \\
Reliability & 0.842 & 5 \\
Citizen Support & 0.884 & 5 \\
\hline
\end{tabular}

Table 4. Importance Perfomance Analysis

\begin{tabular}{|c|c|c|c|c|}
\hline No. & Variable & Perfomance & Epectation & Gap \\
\hline \multicolumn{5}{|c|}{ Efficiency Dimension } \\
\hline 1. & e-Government site address is easy to remember (EF1) & 4.71 & 4.87 & -0.16 \\
\hline 3. & This e-government site's sitemap is well organized (EF3) & 4.50 & 4.51 & -0.01 \\
\hline 4. & This e-Government site's structure is clear and easy to follow (EF4) & 4.65 & 4.89 & -0.24 \\
\hline 5. & This e-government site's search engine is effective (EF5) & 4.52 & 4.60 & -0.07 \\
\hline \multicolumn{5}{|c|}{$\begin{array}{ll} & \text { Trust Dimension } \\
\end{array}$} \\
\hline 1. & Data provided by users in this egovernment site are archived securely (TR1) & 4.30 & 4.62 & -0.32 \\
\hline 2. & Acquisition of username and password in this e-government site is secure (TR2) & 4.60 & 4.60 & 0.00 \\
\hline 3. & Data provided in this e-government site are used only for the reason submitted(TR3) & 4.41 & 4.70 & -0.28 \\
\hline 4. & Maintain the confidentiality of the use of personal data (TR4) & 4.41 & 4.77 & -0.35 \\
\hline \multicolumn{5}{|c|}{$\begin{array}{ll} & \text { Reliability Dimension } \\
\end{array}$} \\
\hline 2. & This e-Government site provides services in time (RE2) & 4.60 & 4.63 & -0.04 \\
\hline 3. & e-Government site's pages are downloaded quickly enough (RE3) & 4.60 & 4.88 & -0.28 \\
\hline 4. & This e-Government site works properly with your default browser (RE4) & 4.57 & 4.85 & -0.28 \\
\hline 5. & The ability to perform promised services accurately (RE5) & 4.35 & 4.66 & -0.30 \\
\hline \multicolumn{5}{|c|}{ Citizen Support Dimension } \\
\hline 1. & Employees showed a sincere interest in solving users' problem (CS1) & 4.49 & 4.89 & -0.40 \\
\hline 2. & Employees have the knowledge to answer users' questions (CS2) & 4.24 & 4.59 & -0.34 \\
\hline 3. & Employees give prompt replies to users inquiries (CS3) & 4.29 & 4.78 & -0.49 \\
\hline 4. & Employees can convey trust and confidence (CS4) & 4.20 & 4.62 & -0.43 \\
\hline \multirow[t]{2}{*}{5.} & There is contact information (CS5) & 4.51 & 4.85 & -0.34 \\
\hline & MEAN & 4,49 & 4,75 & $-0,26$ \\
\hline
\end{tabular}

As mentioned previously, the data from the questionnaire using the e-GovQual approach will be analyzed with the help of IPA (Importance-Performance Analysis) to determine the quality of e-Government services of the Ministry of Law and Human Rights DIY based on the perspective of the user or the public. Furthermore, what is the level of conformity between perceived performance and actual public expectations of e-Government services. The results of the IPA analysis are done by calculating the average value (mean) of each item measured related to service quality that can be presented in Table 4. Based on Table 4, it can be seen that in general for each measurement item, the gap between performance and expectations has a negative 
value with a range between -0.049 to 0.000 . This means that the quality of e-Government services perceived (perception) of respondents can be said to have not met what was expected by the public.

After obtaining the value of performance and interests in each attribute, it is necessary to do the process of mapping the results into the perspective of performance and interests according to its quadrant with the Importance Performance Analysis (IPA), so that the results obtained as in Figure 4.

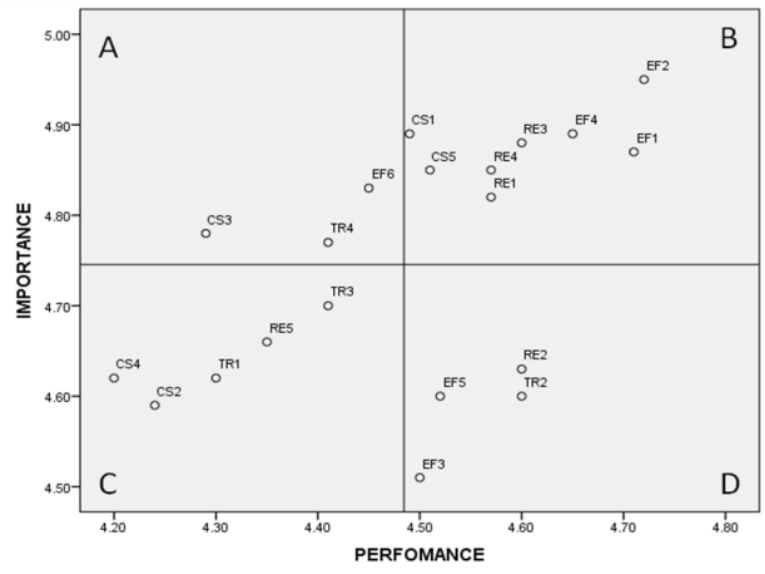

Figure 4. Calculation Results with Importance Performance Analysis (IPA) Methods.

With the IPA analysis as shown in Figure 4, it can be explained which service factors need to be improved as follows:

\section{Quadrant A (Concentrate here)}

Quadrant A are the main priority factors for improving the quality of e-Government services based on public perspectives because these factors are considered important by the public but their performance is still felt to be less or not meeting expectations. The attributes contained in quadrant A, namely:

a. Employees give prompt replies to users inquiries (CS3)

b. Maintain the confidentiality of the use of personal data (TR4)

c. The information displayed in this e-Government site is apppropriate detailed (EF6)

2. Quadrant B (Keep up the good work)

The attributes contained in quadrant $B$, namely:

a. e-Government site address is easy to remember (EF1)

b. The information displayed in this e-Government site is update and fresh (EF2)

c. This e-Government site's structure is clear and easy to follow (EF4)

d. This e-Government site is available and accessible whenever you need it (RE1)

e. e-Government site's pages are downloaded quickly enough (RE3) f. This e-Government site works properly with your default browser (RE4)

g. Employees showed a sincere interest in solving users' problem (CS1)

h. There is contact information (CS5)

3. Quadrant C (Low priority)

The attributes contained in quadrant $\mathrm{C}$, namely:

a. Data provided by users in this egovernment site are archived securely (TR1)

b. Data provided in this e-government site are used only for the reason submitted(TR3)

c. Employees have the knowledge to answer users' questions (CS2)

d. The ability to perform promised services accurately (RE5)

e. Employees can convey trust and confidence (CS4) 4. Quadrant D (Possible overkill)

Quadrant D are factors of public service that are considered less important by the public but are in fact given too much by the government. Thus this causes services to be inefficient because the available resources are focused on improving the performance of public services. The attributes contained in quadrant $\mathrm{C}$, namely:

a. This e-government site's sitemap is well organized (EF3)

b. This e-government site's search engine is effective (EF5)

c. Acquisition of username and password in this egovernment site is secure (TR2)

d. This e-Government site provides services in time (RE2)

Based on the mapping of the quality factors of eGovernment services above, it can help the government especially the Regional Office of the Ministry of Law and Human Rights DIY to make improvements based on priority scale especially the factors of service quality that are still weak but are considered important by the public. Recommendations for improvement will be given to the attributes that are in quadrant $\mathrm{A}$ and quadrant $\mathrm{C}$, so the attributes that need to be improved include:

1. Quadrant A Recommendation (Concentrate Here)

a. Employees give prompt replies to users inquiries (CS3)

b. Maintain the confidentiality of the use of personal data (TR4)

c. The information displayed in this e-Government site is apppropriate detailed (EF6)

2. Quadrant C (Low priority)

a. Data provided by users in this egovernment site are archived securely (TR1)

b. Data provided in this e-government site are used only for the reason submitted(TR3)

c. Employees have the knowledge to answer users' questions (CS2)

d. The ability to perform promised services accurately (RE5)

e. Employees can convey trust and confidence (CS4) 


\section{Discussion}

Based on the results of research that has been conducted related to the quality of public services in the Regional Office of the Ministry of Law and Human Rights DIY can be concluded that the quality of public services is evaluated by the e-GovQual approach consisting of 4 dimensions namely efficiency, trust, reliability and support to the public (citizen support) with a total of 20 valid and reliable measurement variables. Analysis of the gap between service performance and public expectations shows that in general the performance of eGovernment services has run very well even though there is still a slight gap between performance and expectations. From the results of the IPA analysis, it is found that there are 3 (three) e-Government service Concentrate Here factors which are the top priority for improvement. These factors are related to nontechnological factors, namely Employees give prompt replies to users inquiries, Maintain the confidentiality of the use of personal data, The information displayed in this e-Government site is apppropriate detailed. Generally can be concluded that the quality eGovernment service based on user perspective was good enough and met the citizen needs or expectation according to e-GovQual framework. However, government institutions must continue to improve the quality of services to the public in order to realize good governance.

\section{CONCLUSIONS}

The results shows that the quality of public services in the Regional Office of the Ministry of Law and Human Rights DIY can be concluded that the quality of public services is evaluated by the e-GovQual approach consisting of four dimensions namely efficiency, trust, reliability and support to the public (citizen support) with a total of twenty valid and reliable measurement variables.

\section{ACKNOWLEDGMENTS}

The author would like to thank the Regional Office of the Ministry of Law and Human Rights DIY for the opportunity given to research the quality of egovernment services.

\section{REFERENCES}

Herwanto, Dene, Zulfa FI, Euis NSY. 2013. Integration of Service Quality and Importance Performance Analysis Method in Improving Service Quality at SMK plus Laboratorium Indonesia, Karawang. International Journal of Engineering and Applied Sciences 2(3): 1-14.

Indrajit RE. 2002. Membangun Aplikasi E-Government. PT Alex Media Komputindo, Jakarta.

Martilla JA, James JC. 1977. Importance Performance Analysis. Journal of Marketing.American Marketing Association: 77-79.

Napitupulu D. 2016. Analisa Kualitas Layanan e-Government dengan Pendekatan e-Govqual \& IPA. Jurnal Penelitian Pos dan Informatika 6(2): 153-168.

Papadomichelaki X, Mentzas G. 2012. E-GovQual: A multipleitem scale for assessing egovernment service quality. Government Information Quarterly 29: 98-109.

Parasuraman AP, Zeithami VA, Berry LL. 1988. SERVQUAL: A Multiple-item Scale for Measuring Consumer Perceptions of Service Quality. Journal of Retailing 64: 12-40. 
THIS PAGE INTENTIONALLY LEFT BLANK 